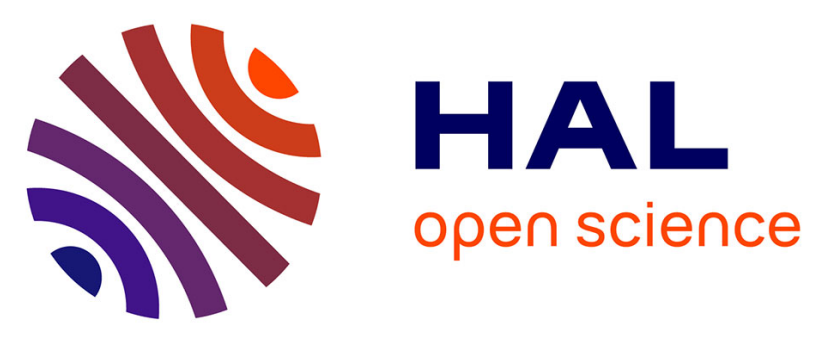

\title{
Candida auris in contemporary mycology labs: A few practical tricks to identify it reliably according to one recent French experience
}

Guillaume Desoubeaux, Eric Bailly, Clémence Guillaume, Marie-Alix de Kyvon, Anne-Charlotte Tellier, Virginie Morange, Louis Bernard, Ephrem Salamé, Roland Quentin, Jacques Chandenier

\section{To cite this version:}

Guillaume Desoubeaux, Eric Bailly, Clémence Guillaume, Marie-Alix de Kyvon, Anne-Charlotte Tellier, et al.. Candida auris in contemporary mycology labs: A few practical tricks to identify it reliably according to one recent French experience. Journal of Medical Mycology = Journal de Mycologie Médicale, 2018, 28 (2), pp.407-410. 10.1016/j.mycmed.2018.02.011 . hal-02439420

\author{
HAL Id: hal-02439420 \\ https://hal.science/hal-02439420
}

Submitted on 17 Jan 2020

HAL is a multi-disciplinary open access archive for the deposit and dissemination of scientific research documents, whether they are published or not. The documents may come from teaching and research institutions in France or abroad, or from public or private research centers.
L'archive ouverte pluridisciplinaire HAL, est destinée au dépôt et à la diffusion de documents scientifiques de niveau recherche, publiés ou non, émanant des établissements d'enseignement et de recherche français ou étrangers, des laboratoires publics ou privés. 


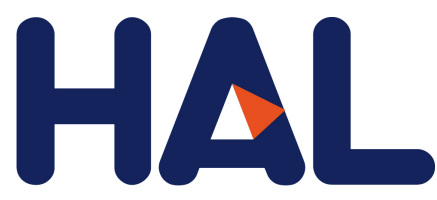

archives-ouvertes

\title{
Candida auris in contemporary mycology labs: A few practical tricks to identify it reliably according to one recent French experience
}

\author{
Guillaume Desoubeaux, Eric Bailly, Clémence Guillaume, Marie-Alix de
}

Kyvon, Anne-Charlotte Tellier, Virginie Morange, Louis Bernard, Ephrem

Salame, Roland Quentin, Jacques Chandenier

\section{To cite this version:}

Guillaume Desoubeaux, Eric Bailly, Clémence Guillaume, Marie-Alix de Kyvon, Anne-Charlotte Tellier, et al.. Candida auris in contemporary mycology labs: A few practical tricks to identify it reliably according to one recent French experience. Journal de Mycologie Médicale, Elsevier Masson, 2018, 28 (2), pp.407-410. 10.1016/j.mycmed.2018.02.011 . hal-02439420

\section{HAL Id: hal-02439420 \\ https://hal.archives-ouvertes.fr/hal-02439420}

Submitted on 17 Jan 2020

HAL is a multi-disciplinary open access archive for the deposit and dissemination of scientific research documents, whether they are published or not. The documents may come from teaching and research institutions in France or abroad, or from public or private research centers.
L'archive ouverte pluridisciplinaire HAL, est destinée au dépôt et à la diffusion de documents scientifiques de niveau recherche, publiés ou non, émanant des établissements d'enseignement et de recherche français ou étrangers, des laboratoires publics ou privés. 


\section{Candida auris in contemporary mycology labs: A few practical tricks to identify it reliably according to one recent French experience}

Keywords:

MALDI-TOF

Haemulonii complex

Candida auris from a 58 year-old-Lebanese man who was hospitalized for liver transplantation because of severe cirrhosis, and how we implemented adequate means for controlling its widespreading.

Two months before arriving in France, the patient travelled in India and Iran for medical purposes. He probably acquired there several highly-resistant microorganisms, e.g. azole-resistant C. glabrata, fluconazole - and echinocandin-resistant Geotrichum fragrans, carbapenem-resistant Escherichia coli, vancomycin-resistant Enterococcus faecium - all isolated from digestive samples -, and a $E$. coli strain with extended spectrum $\beta$-lactamase - in ascites fluid. In addition, a $C$. auris strain was iteratively isolated 11 times in our patient over a 52-day-long period of hospitalization (eight times in throat, one time in rectum, in urines and in peritoneal fluid). On CAN2 ${ }^{\circledR}$ chromogenic culture medium (BioMérieux, Marcy-L'Étoile, France), colonies grew quite slowly at $30-37^{\circ} \mathrm{C}$. They appeared initially whitish, and then displayed a light reddishpink color, very close to this of $C$. kefyr or $C$. tropicalis (Fig. 1A). However, the strain was still able to readily grow at $37-42^{\circ} \mathrm{C}$, and in contrast to the two aforementioned species and to C. haemulonii, its microscopic observation did not show filamentous or pseudofilamentous hyphae (Fig. 2B). Thus, we went ahead with identification testing through MALDI-TOF (matrix associated laser desorption ionization-time of flight) mass spectrometry (MS) [5]. Using the Microflex LT $^{\circledR}$ instrument (Bruker Daltonics, Bremen, Germany) and the software FlexControl ${ }^{\circledR}$ v3.4 with default settings, our MALDI Biotyper Compass IVD ${ }^{\circledR}$ database v4.2.50 was able to suggest $C$. auris as possible species name for $64.71 \%$ attempts (i.e. each isolate was tested in duplicate, but around one third were left unidentified) (Fig. 2). When present in the top-ten identification listing, C. auris was proposed $81.81 \%$ ranked in first position and $72.72 \%$ repeated at least a second time in this listing (mostly in second and third position). However, the log-score values were constantly low, i.e. the mean value was only $1.59 \pm 0.18 / 3$, and the most elevated score was 1.89 which theoretically allows only mild reliability, according to the manufacturer's recommendations. Instead, a lot of bacteria names were suggested among the identification listing, like those belonging to the Actinomycetales order (27.03\% of the top-ten ranking, including Arthrobacter, Agromyces, Corynebacterium, ... species) or the Lactobacillales (13.51\%, e.g. species of the Lactobacillus and Streptococcus genera), Burkholderiales (13.51\%, mostly Burkholderia species), and Pseudomonales (11.71\%, mostly Pseudomonas species) orders. In only $7.20 \%$ cases, alternative fungal names were proposed, including $2.70 \%$ Cryptococcus species which are nonetheless phylogenetically kind very different from Candida species. A posteriori, we thought that these poor results were maybe due to the limited number of validated main mass spectra (MSP) that are referenced in the MALDI Biotyper Compass IVD ${ }^{\circledR}$ database for $C$. auris: only three that come from Japanese (DSM 21092T CBS) and Korean (KCTC_17809 CBS and KCTC_17810 CBS) isolates. Besides according to our experience, the manual full-tube extraction for MS did not better than the direct 

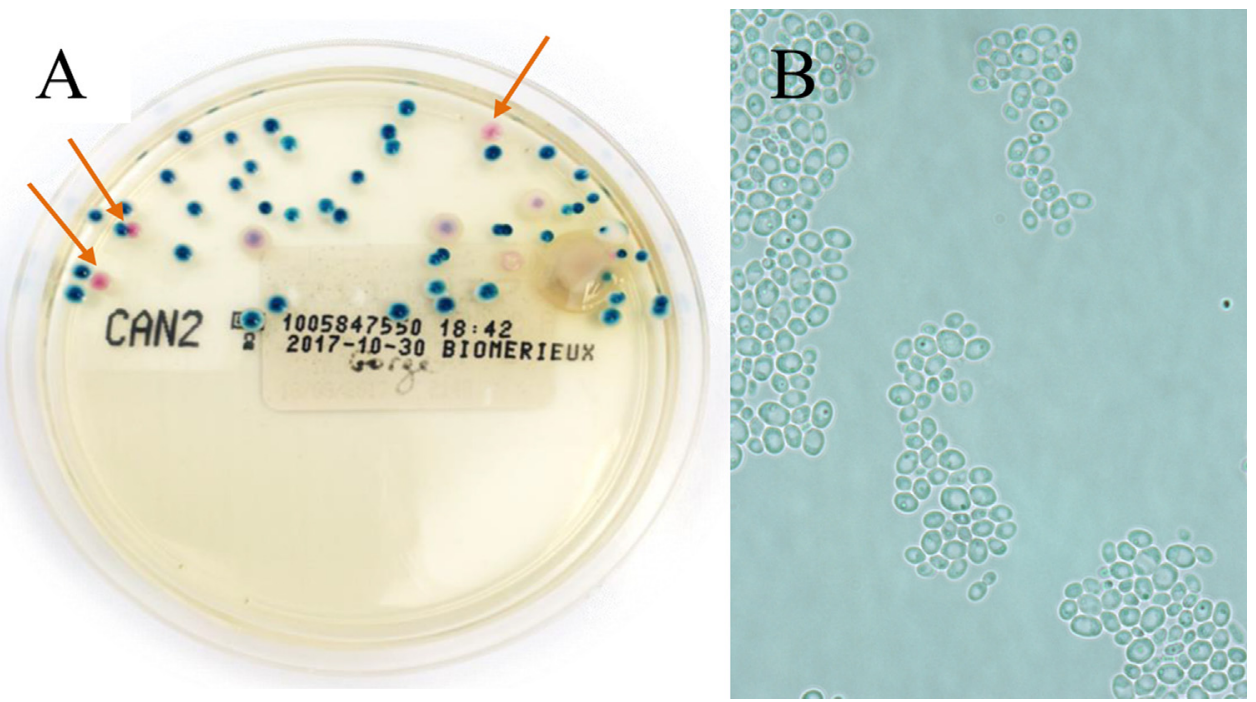

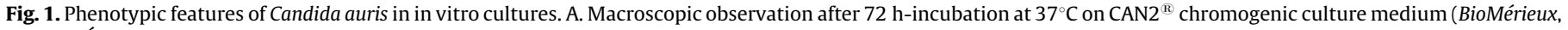

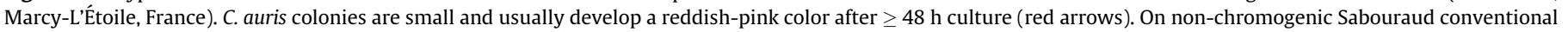

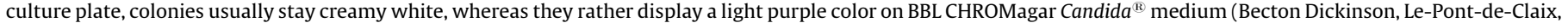

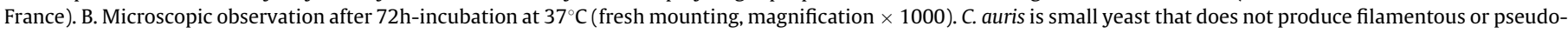
filamentous hyphae, but it can form budding.

on-plate extraction. This finding was contradictory with previous reports [6]. Anyway, strain identification was finally unambiguously confirmed by DNA sequencing of the D1/D2 (query cover $=100 \%$; identity $=99 \%$ of similarity with sequence of UZ1447_15 type strain for 326 bp sequence) and ITS (query cover $=100 \%$; $99 \%$ of similarity with sequence of CBS 10913 type strain for 400 bp sequence) regions. GenBank accession No. MG736297 was granted to the D1/D2 strain sequence. Concomitantly, correct identification was not achievable through auxanogram galleries: API20C ${ }^{\circledR}$ system (BioMérieux, MarcyL'Étoile, France) provided Rhodotorula glutinis (percentage of identification $(\%$ id $)=98.3 \%$; T-index $=0.54$ ) as alternative name (but urease test in tube was of course negative), and ID32C ${ }^{\mathbb{R}}$ biochemical platform (BioMérieux, Marcy-L'Etoile, France) gave Candida sake (\%id $=98.1 \%$; T-index $=0.64$ ), but noteworthy both biochemical galleries don't have $C$. auris in their respective libraries. Thus, we suggest that identification of $R$. glutinis by auxanogram system should trigger additional investigation if fungal colonies are not naturally pink-colored on conventional non-chromogenic culture plates. Besides, Vitek MS ${ }^{\circledR}$ system (BioMérieux, Marcy-L'Étoile, France) didn't succeed in identifying $C$. auris when the test was performed with the current IVD (in vitro diagnosis) v3.2 database, probably because the latter includes no reference MSP for this species yet (same comment with the current Andromas ${ }^{\circledR}$ [Paris, France] MS database). Likewise, Vitek- $2^{\circledR}$ automated instrument (BioMérieux, Marcy-L'Étoile, France) was shown to commonly misdiagnose $C$. auris as other yeast $[2,5]$; besides, an Indian study found that $88.2 \%$ of the 102 clinical isolates, previously identified as $C$. haemulonii or $C$. famata with this system, were actually $C$. auris [5].

Susceptibility of our $C$. auris strain to antifungal drugs was in vitro assessed according to the E-test ${ }^{\mathbb{R}}$ (BioMérieux, Marcy-L'Étoile, France) and EUCAST (European committee for antimicrobial susceptibility testing) methods [7]; elevated minimal inhibition concentrations (MICs) were consistently observed for flucytosine and fluconazole ( $>32 \mathrm{mg} / \mathrm{L}$ ) with both techniques. Anyway, determination of MICs seems critical in light of the high probability of resistance acquisition in C. auris, e.g. 90\% clinical strains display high MIC to fluconazole and 35\% to amphotericin B (herein, MIC for amphotericin B was estimated at $0.5 \mathrm{mg} / \mathrm{L}$ ) [8]. Very recently, some authors proposed specific guidelines defining the MIC breakpoints and the epidemiological cut-off for $C$. auris species [9].

Following the first detection of $C$. auris in our department, we decided to apply very intense means of decontamination $[3,8]$, so that to avoid selection of this strain and its widespreading in our mycology laboratory $[10,11]$. The Center for Diseases Control and prevention (Atlanta $C D C$ ) specifically recommends use of a Environmental Protection Agency (EPA)-registered hospital-grade disinfectant (List $\mathrm{K}$ ) effective against Clostridium difficile spores (https://www.cdc.gov/fungal/diseases/candidiasis/ c-auris-infection-control.html) [12]. Indeed, experimental works recently showed significant higher length of $C$. auris survival on health care surfaces: at day $28,3.0 \log _{10}$ colony forming units (CFU) viable cells vs. $2.6 \mathrm{CFU}$ for $C$. parapsilosis $(P<0.05)$ [10]. Likewise, quaternary ammonium products, e.g. Surfanios Premium ${ }^{\mathbb{R}}$ (Laboratoire Anios, Lille - Hellemmes, France), exhibited poor activity against $C$. auris (in average, reduction of only $1.0 \log _{10}$ CFU vs. 6.0 for Staphylococcus aureus), whereas chlorine, peracetic acid and hydrogen peroxide remained quite effective (respective mean reduction of 6.0, 5.0, and $5.5 \log _{10} \mathrm{CFU}$, like for $C$. albicans, $C$. glabrata and $S$. aureus; $P>0.05$ ) [11]. Herein, every $C$. auris isolate was confined in a sealed plastic bag and moved to the fridge at $+4{ }^{\circ} \mathrm{C}$. Horizontal surfaces, plus all items and furniture that may have come into contact with the strain, were daily cleaned by thorough wet wiping and by application of bleach, $2.6 \%$ chlorine in cold water (Avix Javel ${ }^{\circledR}$ pH12, Coldis, Entraigues-sur-la-Sorgue, France). Floor was similarly treated thrice weekly. Besides, UV treatment was implemented for the microbiological flow hoods during $30 \mathrm{~min}$, instead of $5 \mathrm{~min}$, because data are limited about hands-free disinfection methods. All these efforts were sustained for four weeks following the last isolate [10].

The patient finally died 52 days after hospital admission. Meanwhile, contact individuals were screened thrice by sampling urines, rectum, axillae and throat. Detection was also carried out in exposed patients weekly by cutaneous swabbing of the groins and the axillae. Altogether, no proofs occurred neither for $C$. auris fungemia nor transmission of the strain to other patients of our facility. 

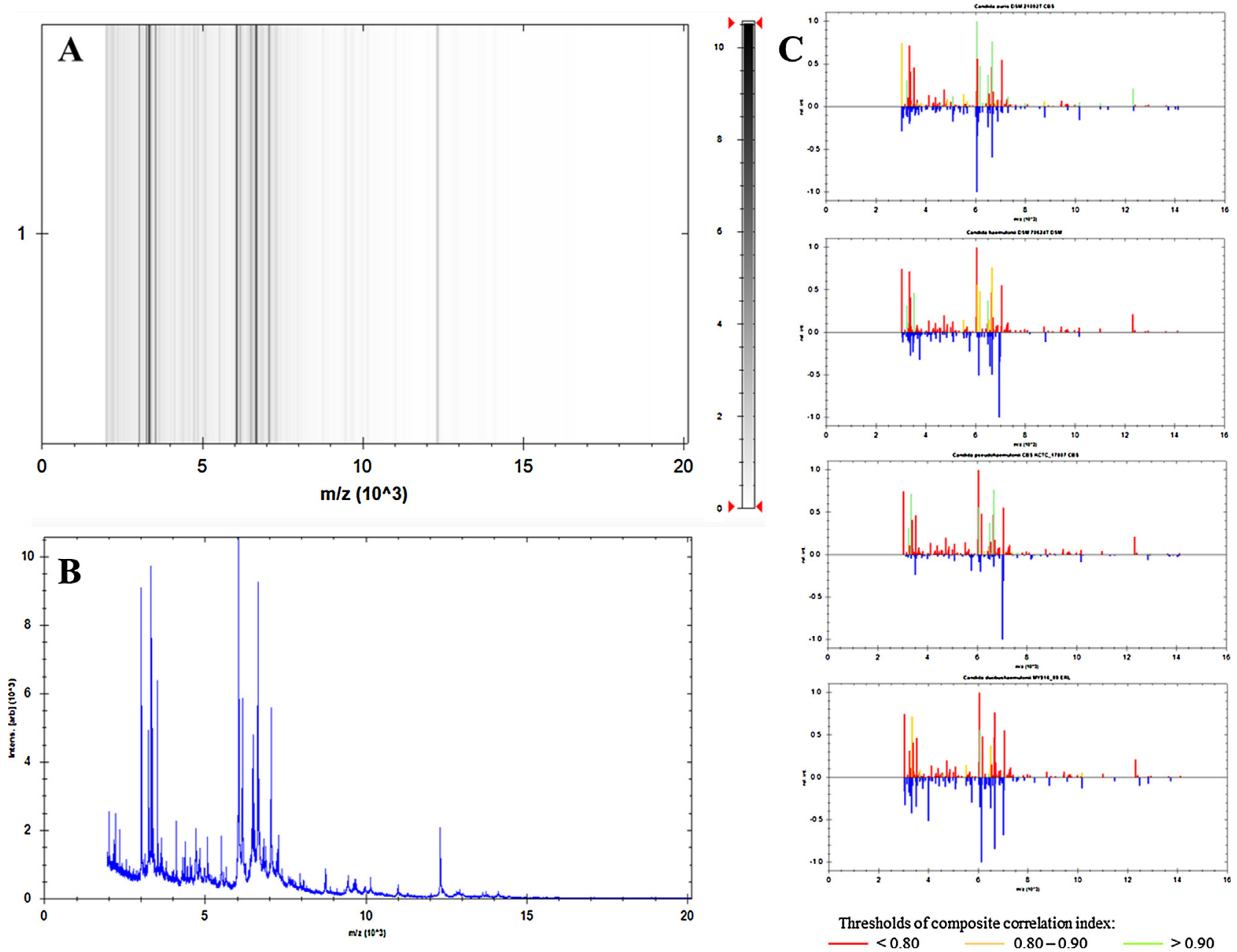

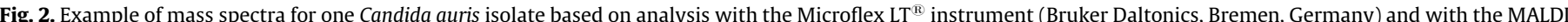

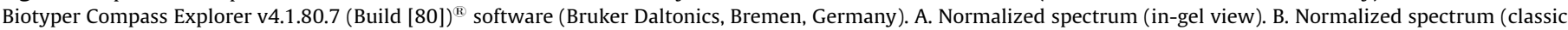

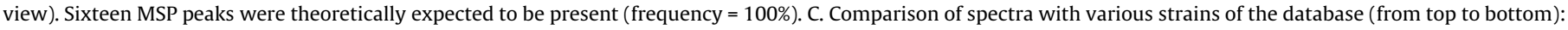

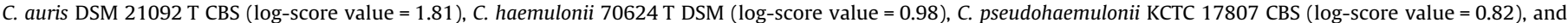

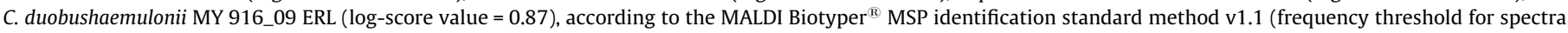

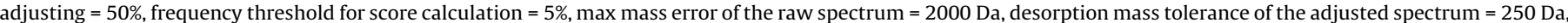

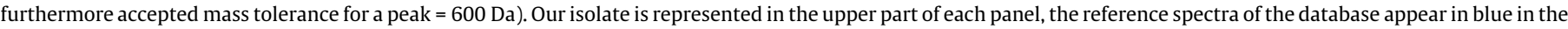

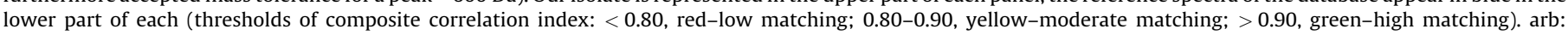
Arbitrary; intens.: Intensity; m: Mass; rel. int.: Relative intensity; z: ionic charge.

In conclusion, mycologists have to stay vigilant when patients come back from tropical countries, especially from Asia but also from Middle East, because they are likely to vehicle unusual and emerging highly-resistant microorganisms, including fungal species like $C$. auris. Although this yeast species remains rare in Western countries, its real prevalence in healthcare settings may have been perhaps underestimated so far, because of unreliable methods of identification [2]. However, it seems critical for clinical mycology laboratories to accurately and rapidly identify this microorganism to aid in preventing healthcare-associated outbreaks. For such a purpose, updating the reference databases with well-identified isolates is imperative.

\section{Funding}

This work was supported by none.

\section{Disclosure of interest}

The authors declare that they have no competing interest. They have submitted the ICMJE form.

\section{Acknowledgment}

We thank the patient for his cooperation and the CNRMA, Institut Pasteur, Paris, France, for its precious help in investigating the case and in confirming the correct identification (special thanks to Dr. Marie Desnos-Ollivier for her thorough reviewing of the manuscript). The authors are also very grateful to Jeannine Brisacier for all the decontamination means she had to apply in the lab.

\section{References}

[1] Satoh K, Makimura K, Hasumi Y, Nishiyama Y, Uchida K, Yamaguchi H. Candida auris sp. nov., a novel ascomycetous yeast isolated from the external ear canal of an inpatient in a Japanese hospital. Microbiol Immunol 2009;53:41-4. http://dx.doi.org/10.1111/j.1348-0421.2008.00083.x.

[2] Kathuria S, Singh PK, Sharma C, Prakash A, Masih A, Kumar A, et al. Multidrugresistant Candida auris misidentified as Candida haemulonii: characterization by Matrix-assisted laser desorption ionization-time of flight mass spectrometry and DNA sequencing and its antifungal susceptibility profile variability by Vitek 2. CLSI broth microdilution, and Etest method. J Clin Microbiol 2015;53:1823-30. http://dx.doi.org/10.1128/JCM. 00367-15.

[3] Schelenz S, Hagen F, Rhodes JL, Abdolrasouli A, Chowdhary A, Hall A, et al. First hospital outbreak of the globally emerging Candida auris in a European 
hospital. Antimicrob Resist Infect Control 2016;5:35. http://dx.doi.org/ 10.1186/s13756-016-0132-5.

[4] Chowdhary A, Sharma C, Meis JF. Candida auris: a rapidly emerging cause of hospital-acquired multidrug-resistant fungal infections globally. PLoS Pathog 2017;13:e1006290. http://dx.doi.org/10.1371/journal.ppat.1006290.

[5] Grenfell RC, da Silva Junior AR, Del Negro GMB, Munhoz RB, Gimenes VMF, Assis DM, et al. Identification of Candida haemulonii complex species: Use of ClinProTools(TM) to overcome limitations of the Bruker Biotyper(TM). Vitek MS(TM) IVD, and Vitek MS(TM) RUO databases. Front Microbiol 2016;7:940. http://dx.doi.org/10.3389/fmicb.2016.00940.

[6] Mizusawa M, Miller H, Green R, Lee R, Durante M, Perkins R, et al. Can multidrug-resistant Candida auris be reliably identified in clinical microbiology laboratories? J Clin Microbiol 2017;55:638-40. http://dx.doi.org/10.1128/ JCM. 02202-16.

[7] Pfaller MA, Andes D, Diekema DJ, Espinel-Ingroff A, Sheehan D. CLSI Subcommittee for Antifungal Susceptibility Testing. Wild-type MIC distributions, epidemiological cutoff values and species-specific clinical breakpoints for fluconazole and Candida: time for harmonization of CLSI and EUCAST broth microdilution methods. Drug Resist Updat Rev Comment Antimicrob Anticancer Chemother 2010;13:180-95. http://dx.doi.org/10.1016/j.drup.2010.09.002.

[8] Government of United Kingdom. Candida auris: laboratory investigation, management and infection prevention and control n.d. https://www.gov. uk/government/publications/candida-auris-laboratory-investigationmanagement-and-infection-prevention-and-control [accessed December 28, 2017].

[9] Arendrup MC, Prakash A, Meletiadis J, Sharma C, Chowdhary A. Comparison of EUCAST and CLSI reference microdilution MICs of eight antifungal compounds for Candida auris and associated tentative epidemiological cut-off values. Antimicrob Agents Chemother 2017;61. http://dx.doi.org/10.1128/AAC.00485-17.

[10] Welsh RM, Bentz ML, Shams A, Houston H, Lyons A, Rose LJ, et al. Survival, persistence, and isolation of the emerging multidrug-resistant pathogenic yeast Candida auris on a plastic health care surface. J Clin Microbiol 2017;55:2996-3005. http://dx.doi.org/10.1128/JCM.00921-17.

[11] Cadnum JL, Shaikh AA, Piedrahita CT, Sankar T, Jencson AL, Larkin EL, et al. Effectiveness of disinfectants against Candida auris and other Candida species. Infect Control Hosp Epidemiol 2017;38:1240-3. http://dx.doi.org/10.1128/ JCM.00921-17.
[12] US EPA O. LIST K: EPA's registered antimicrobial products effective against Clostridium difficile spores. US EPA; 2015 [https://www.epa.gov/ pesticide-registration/

list-k-epas-registered-antimicrobial-products-effective-against-clostridium (accessed February 21 2018)].

G. Desoubeaux ${ }^{\mathrm{a}, *}$, É. Bailly $^{\mathrm{a}}$, C. Guillaume ${ }^{\mathrm{a}}$, M.-A. De Kyvon ${ }^{\mathrm{a}}$, A.C. Tellier ${ }^{\mathrm{b}}$, V. Morange ${ }^{\mathrm{c}}$, L. Bernard ${ }^{\mathrm{d}}$, E. Salamé ${ }^{\mathrm{e}}$, R. Quentin ${ }^{\mathrm{c}, \mathrm{f}}$, J. Chandenier a Service de parasitologie, mycologie, médecine tropicale, pôle de biologie médicale, hôpital Bretonneau, CHU de Tours, $1^{\text {er }}$ étage du Bâtiment B2A,

2, boulevard Tonnellé, 37044 Tours, France

${ }^{\mathrm{b}}$ Réanimation chirurgicale, $\mathrm{CHU}$ de Tours, 37044 Tours, France ${ }^{\mathrm{c}}$ Equipe opérationnelle d'hygiène, CHU de Tours, 37044 Tours, France ${ }^{\mathrm{d}}$ Médecine interne E maladie infectieuse, CHU de Tours, 37044 Tours,

France

'Transplantation hépatique, CHU de Tours, 37044 Tours, France ${ }^{\mathrm{f}}$ Comité de lutte contre les infections nosocomiales, $\mathrm{CHU}$ de Tours, 37044 Tours, France

*Corresponding author E-mail address: guillaume.desoubeaux@univ-tours.fr

(G. Desoubeaux).

Received 31 January 2018 Received in revised form 21 February 2018 Accepted 24 February 2018 Available online $\mathrm{xxx}$ 